\title{
DISEÑO Y CONSTRUCCIÓN DE UN TANQUE DE ALMACENAMIENTO DE GNL EN HUELVA, ESPAÑA
}

(DESIGN AND CONSTRUCTION OF A LNG STORAGE TANK IN HUELVA, SPAIN)

RESUMEN

Se presentan en este número una serie de artículos, cuyo contenido se resume a continuación y que, en su conjunto, da una idea global de esta singular realización ingenieríl.

El Plan de Gasificación de España, se propone duplicar el consumo de gas natural en el período 1985-1992, para llevarlo a un $6 \%$ de participación en el balance de energía primaria en 1992. El esfuerzo necesario para cumplir el Plan es considerable. Entre sus actividades merece destacarse la realización del Terminal de GNL de Palos de la Frontera (Huelva), y como parte singular del mismo su primer tanque de almacenamiento de GNL de $60.000 \mathrm{~m}^{3}{ }^{3}$ de capacidad neta.

El planteamiento para el diseño, construcción y puesta en marcha del tanque, se ha basado en un sistema de contratación llave en mano a un solo contratista que adquiera la responsabilidad completa con precio y plazo fijo. La adjudicación recayó en la oferta presentada por ENTRECANALES y TAVORA, S. A. y SOCIETE NOUVELLE CONSTRUCTIONS METALLIQUES DE PROVENCE qUe SE constituyeron para su desarrollo en Unión Temporal de Empresas (EPH), y que, con un esfuerzo de coordinación importante han tenido una actuación de equipo homogéneo e integrado, con el resultado de cumplimiento de los plazos y niveles de calidad fijados.

El tanque de almacenamiento es un depósito autoportante del tipo doble pared hormigón-acero, cuyo diseño responde a exigencias estrictas de proyecto y a condicionantes de su emplazamiento. Asi entre los parámetros de diseño resaltan la temperatura interior $\left(-170^{\circ} \mathrm{C}\right)$, Boll-off $(0,05 \%)$, Sismo $(0,28 \mathrm{~g}-$ OBE y $0,34 \mathrm{~g} \mathrm{SSL})$, Burn-out $(72 \mathrm{~h})$, Impacto $(2.000 \mathrm{~kg}$ a $50 \mathrm{~m} / \mathrm{s})$, etcétera.

El depósito de hormigón exterior, doblemente postesado, consta de una losa construida en dos fases para dar libertad de movimiento al muro cilíndrico que se ejecuta por tongadas completas, con encofrado trepante, y que se remata con una cúpula esférica, hormigonada sobre un forro interior de acero montado sobre la losa de cimentación y posteriormente elevado con aire. El depósito interior de acero $9 \% \mathrm{Ni}$, se monta introduciendo en el interior del deposito exterior las chapas prefabricadas y curvadas previamente y colocándolas en posición y soldándolas con ayuda de carros motorizados y máquinas automáticas que circulan por un carril fijado a la cúpula.

La organización de Garantia de Calidad ha integrado todas las actividades, elaborando a partir de la normativa básica aplicable, especificaciones y procedimientos de detalle, y caracterizando los materiales utilizados mediante ensayos de homologación y control, con verificaciones y determinaciones de propiedades físicas de los mismos a temperaturas criogénicas, realizadas en laboratorios especializados, coordinados por el de Materiales de Construcción de IBERINSA y dirigidos por el Profesor Elices.

Las experiencias y resultados obtenidos han permitido una discusión de los aspectos esenciales de las Prescripciones desarrrolladas por KELLOGG proponiéndose alternativas a sus puntos más conflictivos.

\section{SUMMARY}

This issue contains a number of articles, contents of which are summarized below, giving an overall idea of this oustanding engineering accomplishment.

The National Gas Scheme intends to duplicate the consumption of natural gas during the period 1985-1992 to reach $6 \%$ participation in the provision of primary energy by 1992. It is essential a great effort to meet the requirements of this Scheme. Among the activities included in the Scheme, we shall mention the construction of a LNG Terminal at Palos de la Frontera, Huelva, Spain, with the singular first 60,000 cubic meter net capacity LNG Storage Tank.

Design, construction and commisioning of the tank was made on a turn-key basis to only one contractor who assumed the overall responsability with fixed cost and completion date. The project was awarded to the Joint Venture ENTRECANALES Y TAVORA, S. A. and SOCIETE NOUVELLE CONSTRUCTIONS METALLIQUES DE PROVENCE. The important coordination effort and the work conducted by an homogeneous and integrated team have resulted in the fulfillment of quality requirements on the specified dates.

The storage tank is a self-supporting structure of steelconcrete double wall type. The desing conforms to rigid project requirements and location conditions. Among the design parameters it should be remarked the internal temperature of $-170{ }^{\circ} \mathrm{C}$, Boil-off 0,05\%, Seism 0,28 g OBE and 0,34 g SSE, Burn-out $72 \mathrm{~h}$, Impact 2,000 kg. at $50 \mathrm{~m} / \mathrm{s}$, etc.

The external concrete tank, doubly post-tensioned is composed of a slab made in two stages to free from movememt the cylinder wall which is concreted in layers using slipforms. It is topped with a spherical dome that was concreted on a steel liner that was erected on the foundation slab and then raised to position by compressed air. The inner container, $9 \% \mathrm{Ni}$ steel, is erected by introducing the prefabricated and previously curved plates inside the external tank. They are then placed into position and welded with the assistance of motor cars and automatic (welding equipment) that run on a rail anchored to the dome.

The Quality Assurance organization integrated all activities and on the basis of the applicable regulations, it has prepared specifications and detail procedures. The material used was characterized through homologation and control tests, with verification and determination of physical properties of such materials at cryogenic temperatures. The tests were conducted at specialized laboratories under the coordination of the IBERINSA Construction Materials Laboratory under the direction of Professor Elices. The experience and results obtained have permitted a discussion of the essential aspects of the Prescriptions developed by KELLOGG suggesting alternates to his most conflictive items. 